\title{
CITRA REPETISI DALAM SENI GRAFIS
}

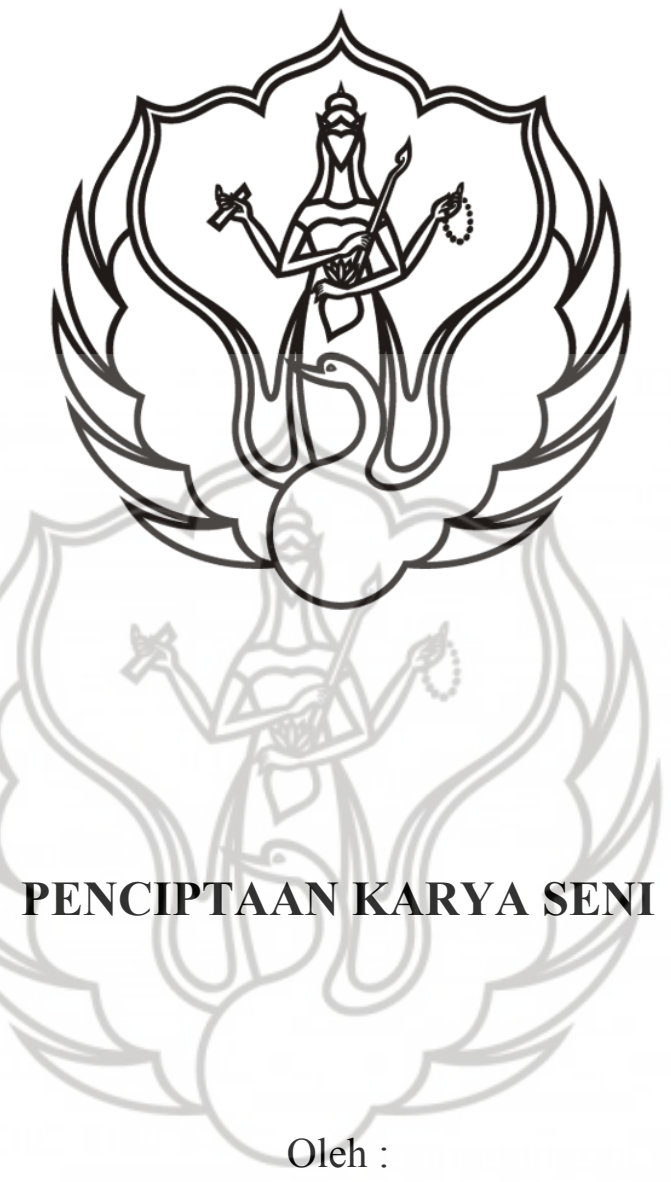

Munif Rafi Zuhdi

NIM : 1312438021

PROGRAM STUDI SENI RUPA MURNI

JURUSAN SENI MURNI FAKULTAS SENI RUPA

INSTITUT SENI INDONESIA YOGYAKARTA

2018

UPT Perpustakaan ISI Yogyakarta 


\section{CITRA REPETISI DALAM SENI GRAFIS}

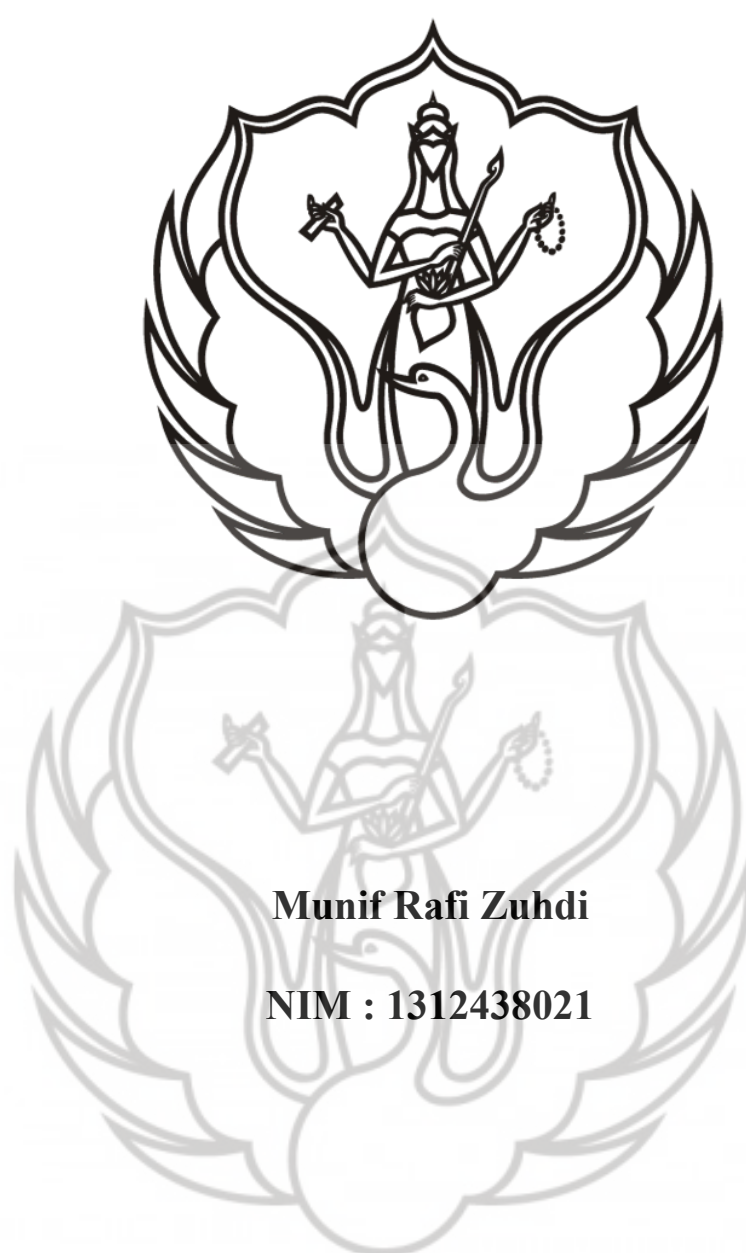

Tugas Akhir ini Diajukan kepada Fakultas Seni Rupa

Institut Seni Indonesia Yogyakarta Sebagai

Salah Satu Syarat untuk Memperoleh

Gelar Sarjana S-1 dalam Bidang

Seni Rupa Murni

2018

\section{UPT Perpustakaan ISI Yogyakarta}


Tugas Akhir Karya Seni berjudul :

CITRA REPETISI DALAM SENI GRAFIS diajukan oleh Munif Rafi Zuhdi, NIM 1312438021, Program Studi Seni Rupa Murni, Jurusan Seni Murni, Fakultas Seni Rupa Institut Seni Indonesia Yogyakarta, Telah dipertanggungjawabkan di depan Tim Penguji Tugas Akhir pada tanggal 17 Januari 2019 dan dinyatakan telah memenuhi syarat untuk diterima.

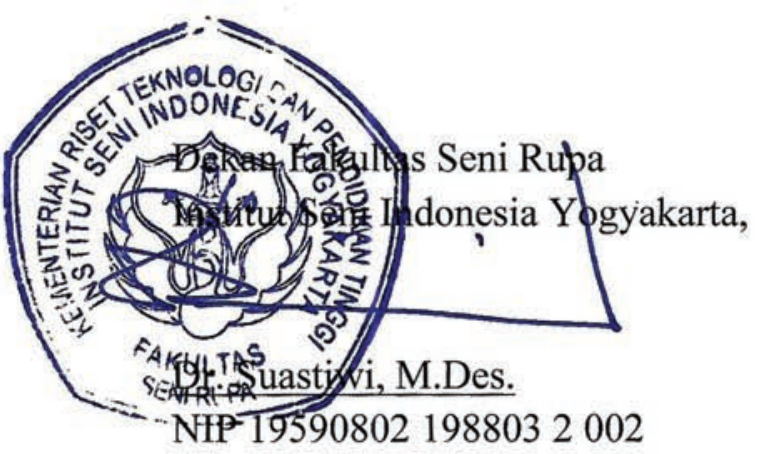

Pembimbing

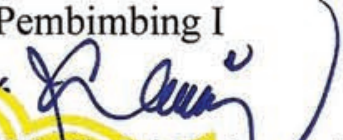

Wintik Sri Wulandari, M.Sn.

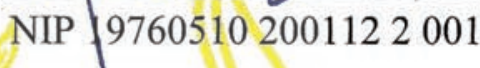

Pembimbing $y$

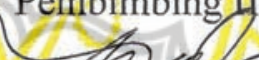

Warsono, S.Sn, MA

NIP 197605092003121001

Cognate/Anggota

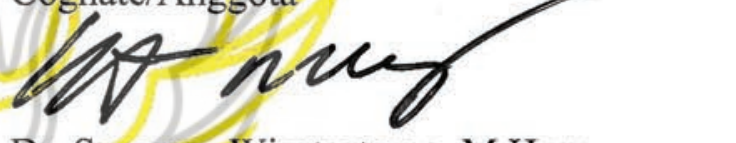

Dr. Suwarno Wisetrotomo, M.Hum

NIP 196204291989021001

Ketua Jurusan Seni

Murni/Ketua/Anggota

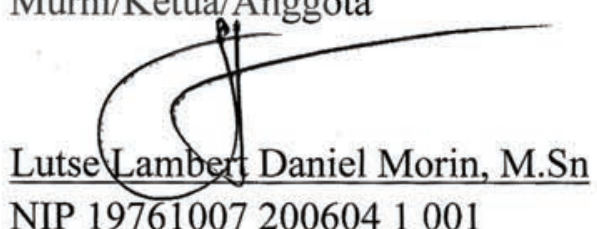

NIP 197610072006041001

\section{UPT Perpustakaan ISI Yogyakarta}


MOTTO

Seniman itu mengada, bukan mengada-ada.

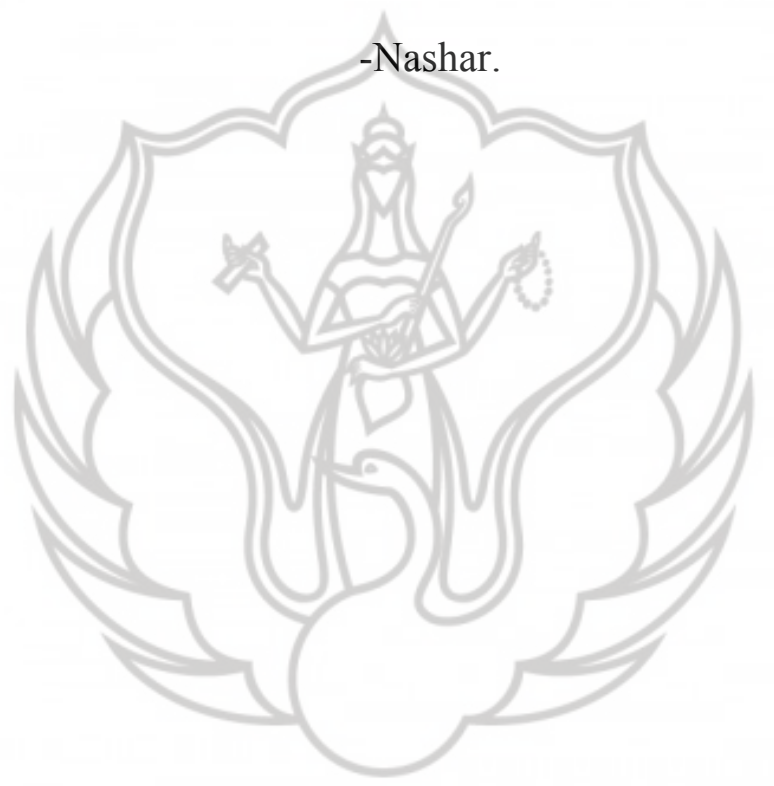

\section{UPT Perpustakaan ISI Yogyakarta}




\section{SURAT PERNYATAAN KEASLIAN TUGAS AKHIR}

Saya yang bertandatangan di bawah ini:

Nama

NIM

Program Studi
: Munif Rafi Zuhdi

: 1312438021

: Seni Rupa Murni

Judul Karya Tugas Akhir : Citra Repetisi Dalam Seni Grafis

Menyatakan dengan sesungguhnya karya tulis tugas akhir dan karya seni tugas akhir ini benar-benar saya kerjakan sendiri. Karya tugas akhir ini bukan merupakan plagiarisme, pencurian hasil karya milik orang lain, hasil kerja orang lain untuk kepentingan saya karena/hubungan material maupun hubungan non material, ataupun segala kemungkinan lain yang pada hakekatnya bukan merupakan karya tulis dan karya seni tugas akhir saya secara orisinil dan otentik.

Bila kemudian hari diduga kuat ada ketidaksesuaian antara fakta dengan pernyataan ini, saya bersedia diproses oleh tim Fakultas yang dibentuk untuk melakukan verifikasi, dengan sanksi terberat/berupa pembatalan kelulusan/kesarjanaan.

Pernyataan ini saya buat dengan kesadaran sendiri dan tidak atas tekanan ataupun paksaan dari pihak manapun demi menegakkan integritas akademik di institusi ini.

Yogyakarta, 28 Desember 2018

Saya yang menyatakan,

Munif Rafi Zuhdi 


\section{KATA PENGANTAR}

Puji syukur dipanjatkan kepada Tuhan Yang Maha Esa karena atas berkah dan ridho-Nya Tugas Akhir Penciptaan Karya Seni ini dapat diselesaikan. Sebagai salah satu syarat kelulusan jenjang pendidikan Strata 1-S1 Minat Utama Seni Murni Grafis, Fakultas Seni Rupa, Institut Seni Indonesia Yogyakarta.

Tugas Akhir ini dapat diselesaikan tentunya berkat bantuan dari banyak pihak. Untuk itu, dengan segala kerendahan hati penulis mengucapkan terima kasih sebesar-besarnya kepada :

1. Wiwik Sri Wulandari, M.Sn., selaku dosen pembimbing I yang telah banyak memberikan saran serta dukungan.

2. Warsono, S.Sn, MA., selaku dosen pembimbing II yang telah banyak memberikan bimbingan serta saran.

3. Dr. Suwarno Wisetrotomo, M.Hum selaku cognate.

4. A.C. Andre Tanama, M.Sn., selaku dosen wali yang telah membimbing sejak awal masa perkuliahan.

5. Lutse Lambert Daniel Morin, M.Sn., selaku Ketua Jurusan Seni Murni.

6. Satrio Hari Wicaksono, S.Sn., M.Sn. selaku wakil Ketua Jurusan Seni Murni, yang juga sempat merangkap sebagai dosen wali.

7. Seluruh Dosen Seni Rupa Murni ISI Yogyakarta yang telah berbagi ilmu pengetahuan selama proses akademik, maupun diluar kegiatan akademik.

8. Seluruh staf dan karyawan Fakultas Seni Rupa Murni ISI Yogyakarta.

9. Kedua orang tua Bapak Zaenudin dan Ibu Maimusaroh yang selama ini rela membagi pundi - pundi untuk anak - anaknya. Adik penulis Zahwa Disa Fahira yang menjadi pendorong untuk melakukan hal yang lebih baik.

10. Keluarga besar penulis yang selalu menanyakan kapan lulus kuliah.

11. Teman - teman kontrakan : Cecep, Cempe, Galih, Danang dan Jarwo yang rela berbagi ruang.

\section{UPT Perpustakaan ISI Yogyakarta}


12. Hang, Uti, Sarah dan Rangga, Jaka, Borat, Forrest, Siam, Setiyoko, Justin, Leo, Anis, Kukuh atas segala bantuan moriil dan materiilnya semoga hidup kalian selalu mendapat berkah.

13. Teman-teman Seni Grafis 2013 (SEREMIS), Teman-teman mahasiswa Seni Murni angkatan 2013 ISI Yogyakarta.

14. Para apresiator yang telah melegakan waktunya untuk melihat presentasi Tugas Akhir penulis dan melengkapi karya penulis dengan apresiasinya yang unik.

15. Untuk semua teman dan saudara yang tidak dapat saya sebutkan satu persatu, yang telah membantu selama proses pengerjaan tugas akhir ini serta memberi dukungan.

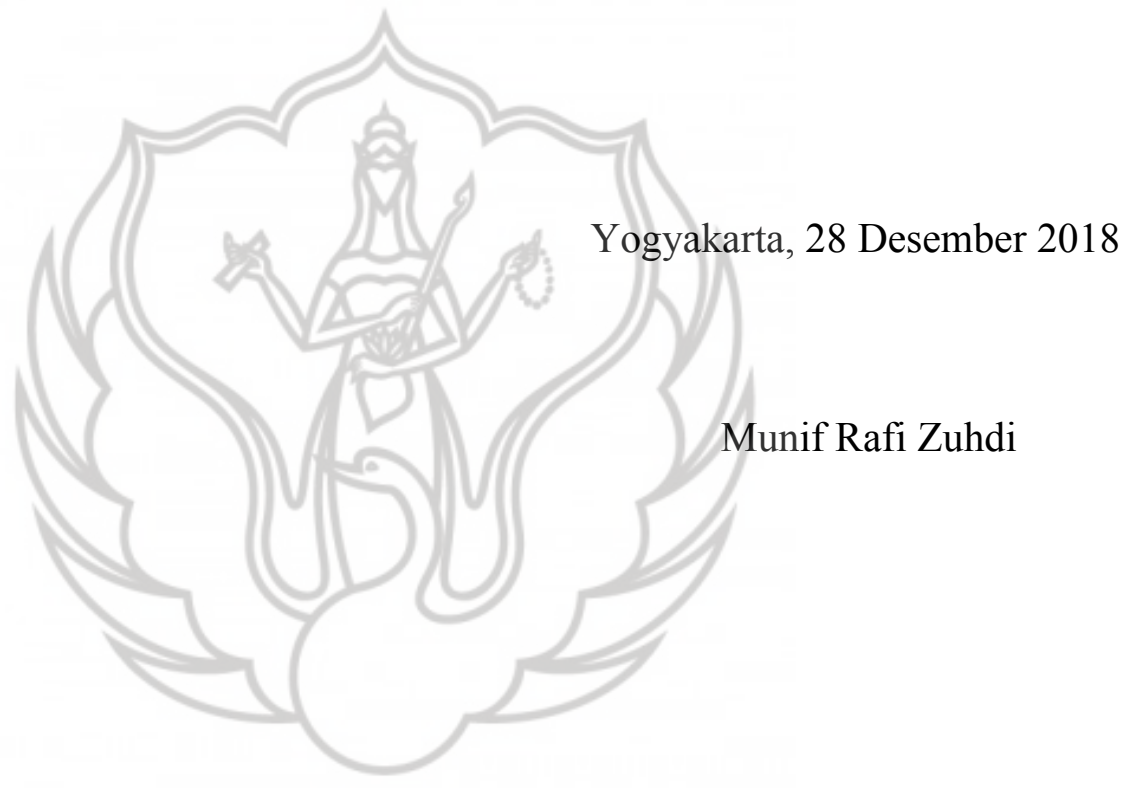




\section{DAFTAR ISI}

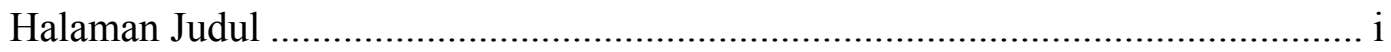

Halaman Pengesahan .................................................................................. ii

Halaman Persembahan/Motto ........................................................................... iii

Surat Pernyataan Keaslian ..................................................................... iv

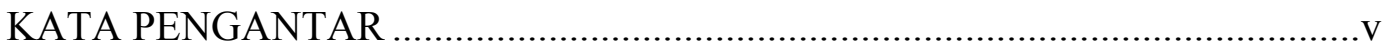

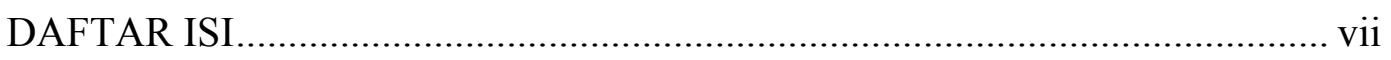

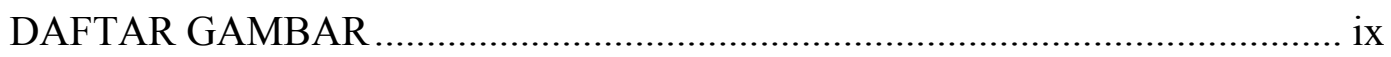

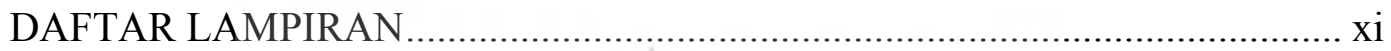

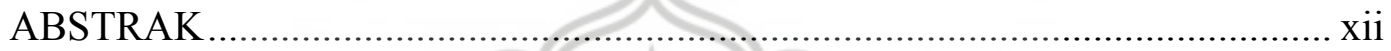

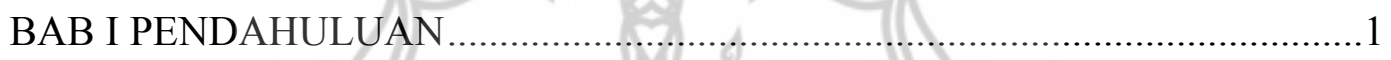

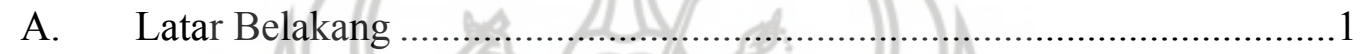

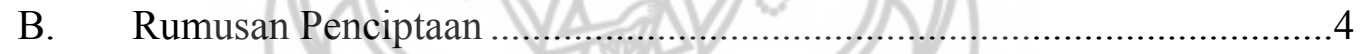

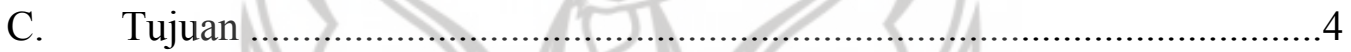

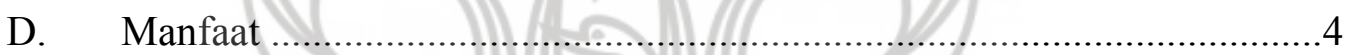

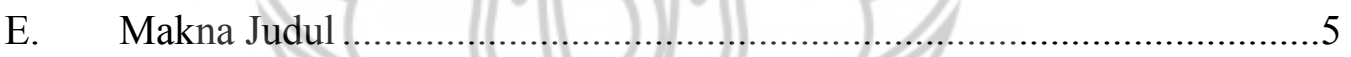

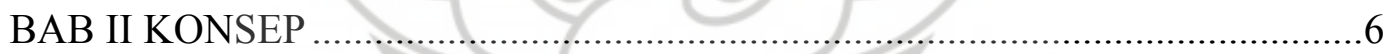

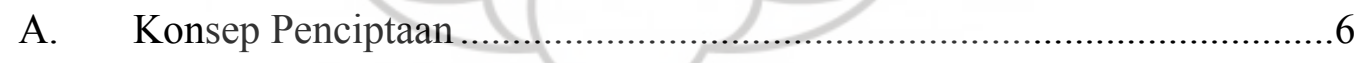

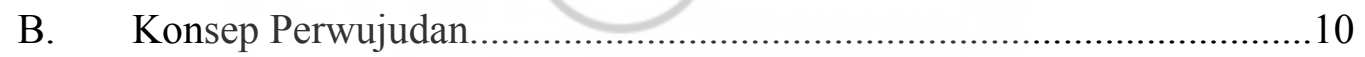

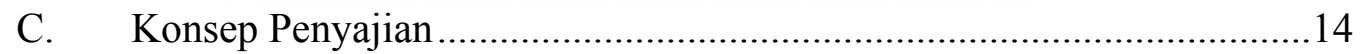

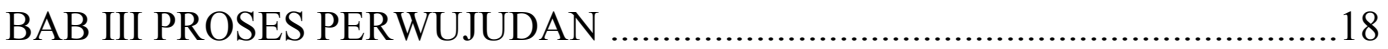

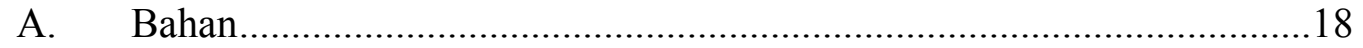

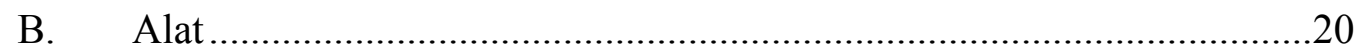

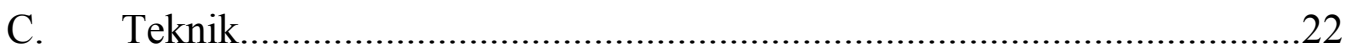

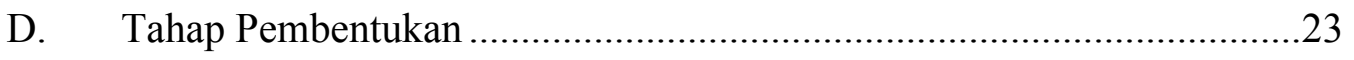

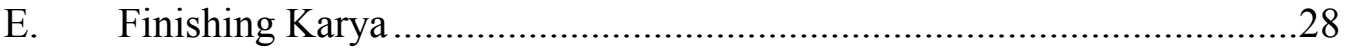

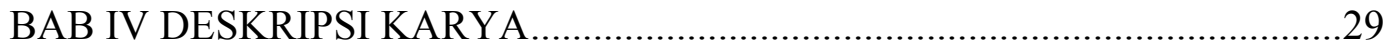

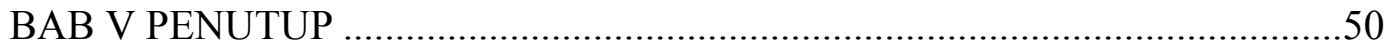



A. Biodata \& CV. .55

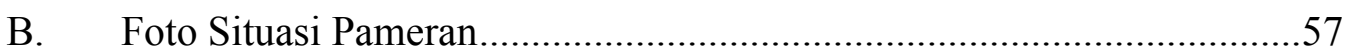

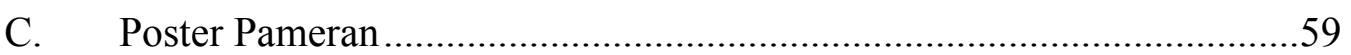

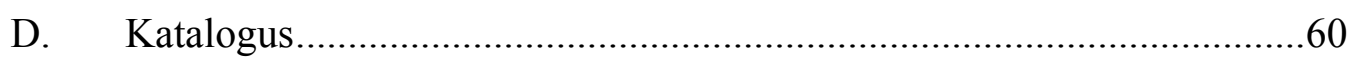

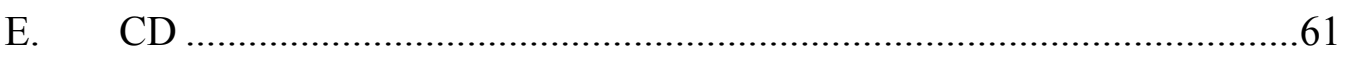

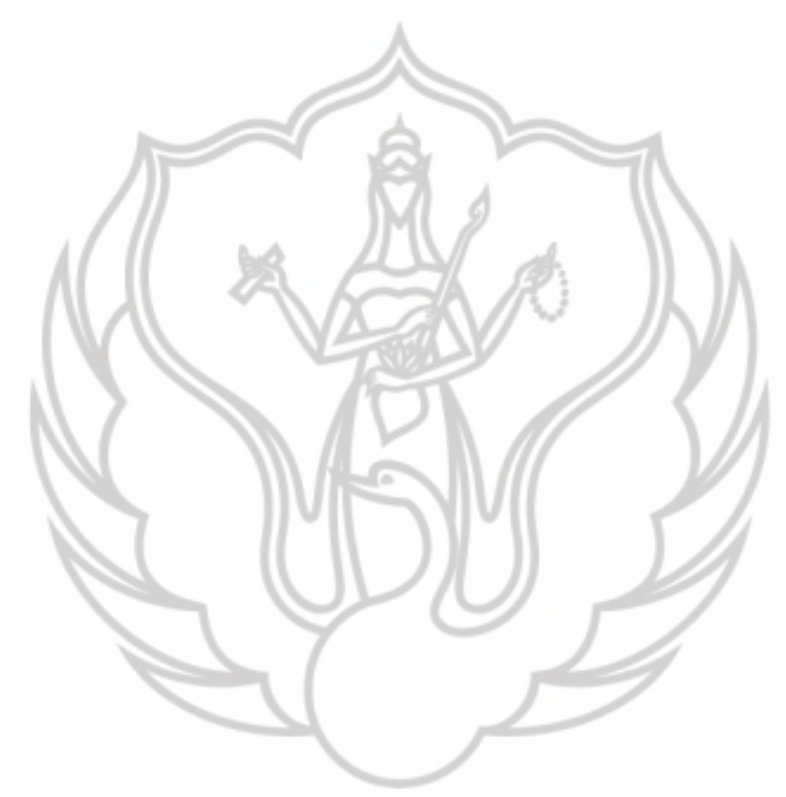

\section{UPT Perpustakaan ISI Yogyakarta}




\section{DAFTAR GAMBAR}

\section{BAB II}

Gb.1. Andy Warhol, "Brillo Box (Soap Pads)", 1964

Gb.2. John Hitchock, "They're Moving Their Feet - But Nobody's Dancing", 2007 16

Gb.3. Foto karya dan cara penyajiannya \#1 .................................................... 17

Gb.4. Foto karya dan cara penyajiannya \#2................................................. 17

\section{BAB III}

Gb.5. Bahan sablon .19

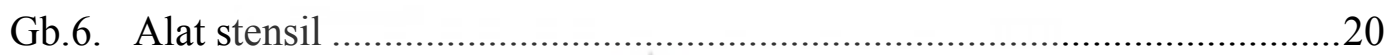

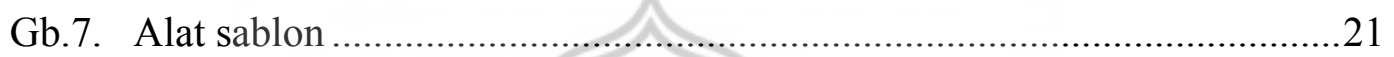

Gb.8. Proses perancangan pada komputer ......................................................2 24

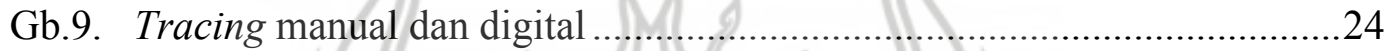

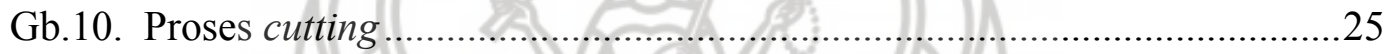

Gb.11. Mengaplikasikan emulsi pada screen ...............................................26

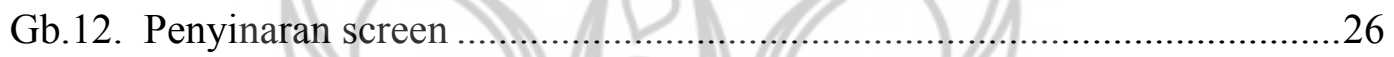

\section{BAB IV}

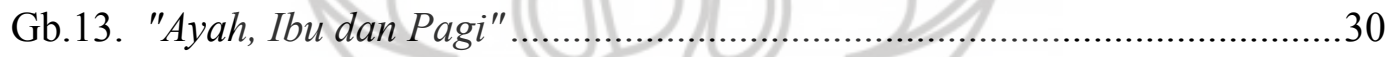

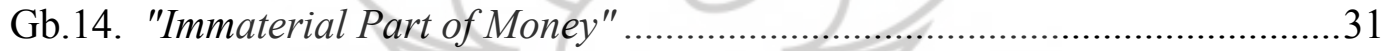

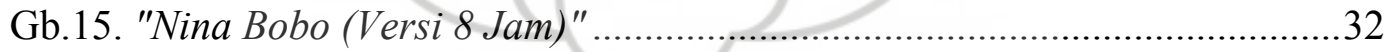

Gb.16. "Melangkah, Melihat, Merasakan, Memilih, Memiliki" ...........................33

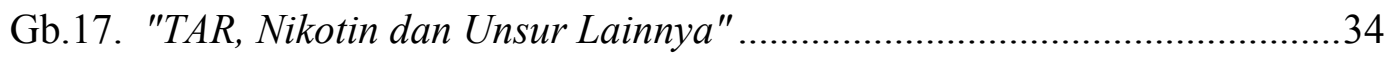

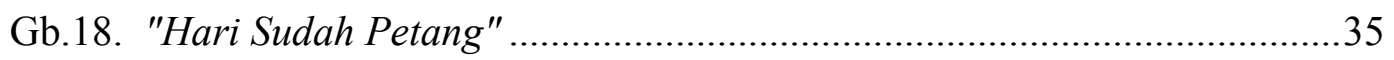

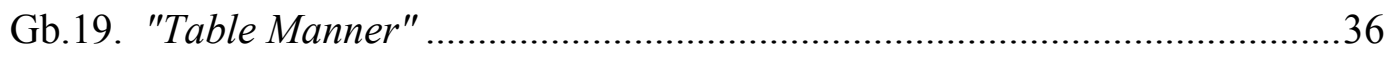

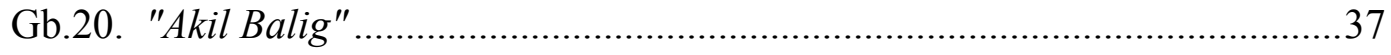

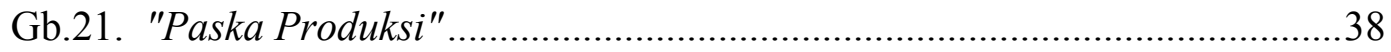

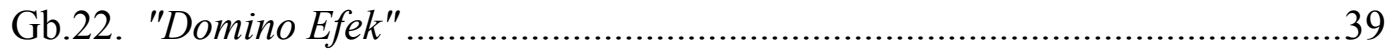

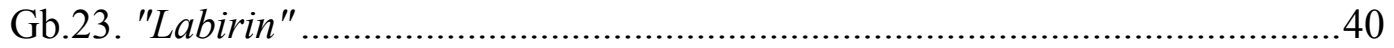

Gb.24. "Kaki Yang Bergerak Tetapi Bukan Menari" ........................................41

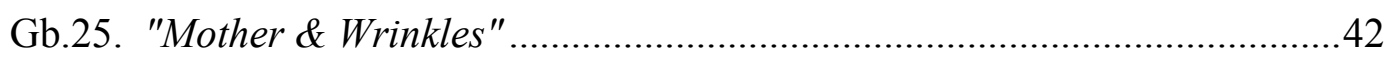

Gb.26. "Rem, Gas dan Beberapa Kilometer" ..................................................43 
Gb.27. "Hujan Di Sepetak Tanah" .44

Gb.28. "Bathroom Manner". .45

Gb.29. "Berganti Kulit" .46

Gb.30. "Deep Sleep". .47

Gb.31. "Perjamuan" .48

Gb.32. "Table Manner \#2" .49

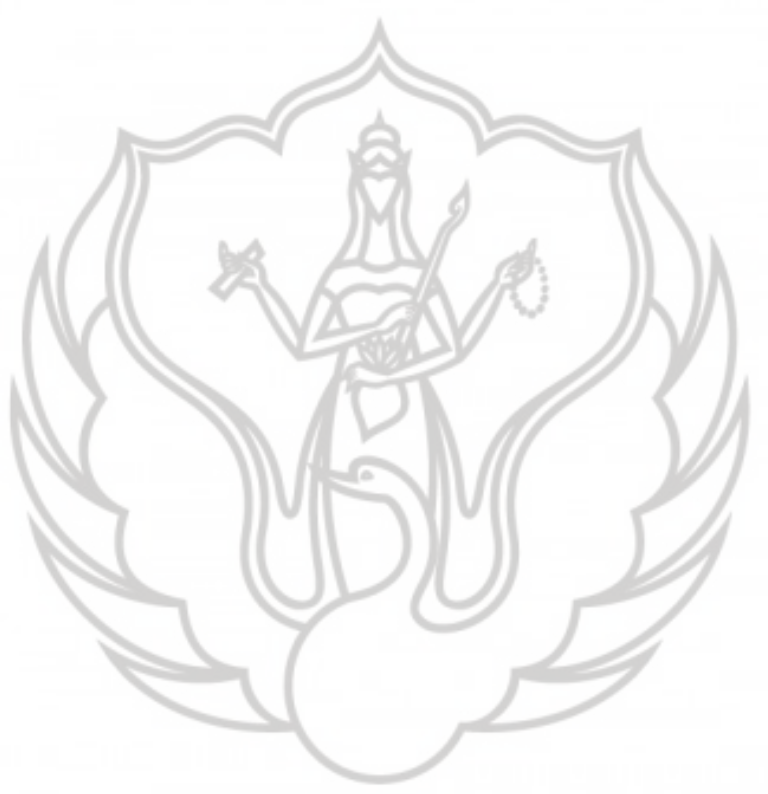

\section{UPT Perpustakaan ISI Yogyakarta}




\section{DAFTAR LAMPIRAN}

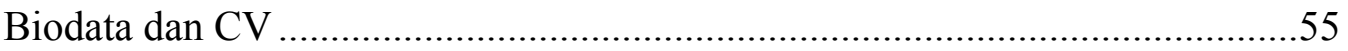

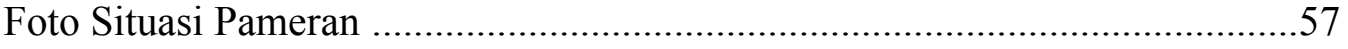

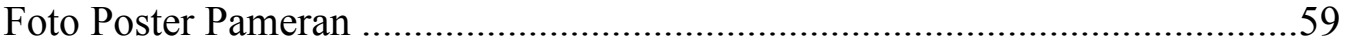

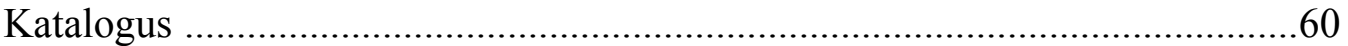

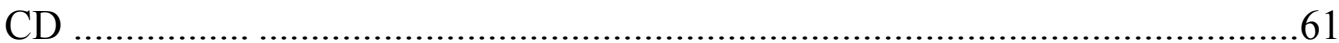

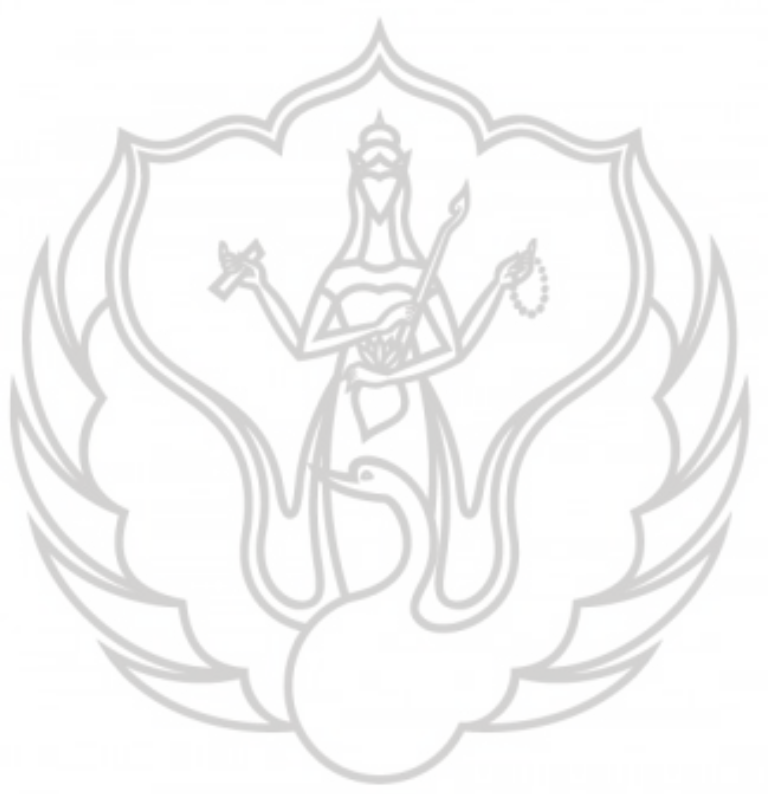

\section{UPT Perpustakaan ISI Yogyakarta}




\begin{abstract}
ABSTRAK
Seni grafis mempunyai beberapa kaidah yang menjadikan seni grafis dapat dibedakan dengan seni lukis atau seni patung. Kaidah tersebut telah disepakati oleh para pelaku seni setelah penggunaan seni grafis sebagai media berekspresi. Kaidah-kaidah tersebut yaitu terdapatnya proses mencetak, terdapatnya matriks cetakan, mempunyai edisi serta berwujud dua dimensi. Tetapi, kaidah tersebut juga terdapat pada hal lain di luar seni grafis. Salah dua hal tersebut adalah rutinitas dan jejak. Hubungan rutinitas dan seni grafis terdapat pada sifat keduanya yang repetitif, dimana dalam rutinitas manusia selalu mengulangi prosedur atau langkah yang sama maupun identik dengan langkah-langkah sebelumnya. Dalam seni grafis, sifat repetitif ada pada kaidah edisi yang membolehkan hasil cetak karya memiliki jumlah lebih dari satu. Meskipun terdapat lebih dari satu hasil, tetapi hasil tersebut merupakan sebuah karya otentik bukan sebagai duplikat. Sedangkan, jejak berhubungan dengan seni grafis karena dalam proses penciptaan jejak (tidak semua) terdapat proses mencetak yangmana merupakan kaidah utama seni grafis. Penulis menggunakan teknik sablon, stensil dan monoprint dalam mengaktualisasikan ide-ide yang didapat untuk dieksekusi ke dalam karya. Karya pada Tugas Akhir ini mencoba memaknai hal-hal sederhana yang ada pada kehidupan sehari-hari manusia dan melihat lebih jauh lagi dari apa yang tersembunyi di dibalik hal-hal tersebut. Melalui Tugas Akhir ini penulis berharap dapat menambah khasanah seni grafis dari segi teknik maupun wacana.
\end{abstract}

Kata Kunci : Jejak, Seni Grafis, Rutinitas, Repetisi

\title{
UPT Perpustakaan ISI Yogyakarta
}




\begin{abstract}
Printmaking consists of different conventional theories which supports printmaking itself could be distinguished by other visual art media like painting and sculpture. The conventional theory basically defined by the makers who mainly explored printmaking as the media of expression of art from the past. The theory mainly included the process of printing, matrix, edition of print and twodimensional outcome. However, out of the conventional theory, the habitual performance and imprint are two of the crucial elements that could be related to the printmaking. The relationship between habitual performance and printmaking happened in the nature of repetition. The repetition of the same procedure or identical gesture in the routine of daily's activity creates a similarity with the theory of printmaking, which is the process print repetitively more than one edition. Even though more than one edition, the outcome still defined as an authentic piece, not duplication. Meanwhile, imprint is related to printmaking as in the process of creating imprint involved printing, which is the main element in printmaking. All these inspired the author to visualize into the work of art by applying the printmaking techniques such as silkscreen printing, stencil, and monoprint. From the making until the final touch of the work finally formed in this final presentation, it tried to contextualize the meaning of the mundane activity and the possibilities of all these activities could be created or explored. Through this presentation, the author hopes to contribute to the repertoire of printmaking in terms of technique and discourse
\end{abstract}

Keywords : Imprint, Printmaking, Habitual performance, Repetition

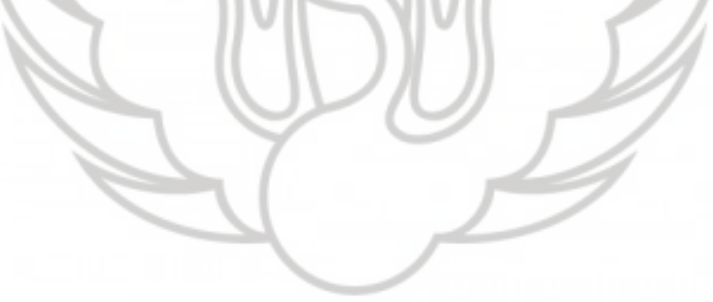




\section{BAB I \\ PENDAHULUAN}

\section{A. Latar Belakang}

Perjalanan merupakan proses yang menunjukkan adanya perpindahan, pergerakan atau aksi dari suatu titik awal menuju titik akhir. Dalam hidupnya mahkluk hidup selalu melakukan perjalanan entah itu perjalanan fisik ataupun mental. Keduanya saling beriringan.

Saat ini penulis juga merasa sedang melakukan salah satu perjalanan, yaitu perjalanan tentang seni grafis. Awal mula perjalanan ini jika dirunut adalah sebelum penulis dilahirkan. Ketika ayah penulis mendirikan Percetakan. Meskipun pekerjaan orang tua penulis berkaitan dengan teknik-teknik seni grafis dan tumbuh dalam lingkungan Percetakan, penulis tidak sempat belajar tentang teknis seni grafis dan tidak tahumenahu tentang seni grafis, dikarenakan bergesernya usaha percetakan orang tua penulis menjadi usaha lain. Baru pada saat kuliah, penulis mengetahui apa itu seni grafis, pada saat kuliah inilah penulis mengetahui tentang seni grafis lebih dalam.

Setelah mengerti sedikit banyak tentang seni grafis, penulis merasa bahwa seni grafis ternyata selalu berada di sekitar penulis dan penulis sendiri sebelumnya tidak sadar akan hal tersebut. Salah satu manifestasi bahwa seni grafis berada di sekitar penulis adalah pertama pada pekerjaan orang tua penulis dan kedua adalah pada studi yang ditempuh oleh penulis. Pada perkerjaan orang tua, penulis melihat bahwa seni grafis dalam konteks tersebut adalah seni grafis sebagai seni terapan, yang artinya teknik-teknik dalam seni grafis digunakan untuk memproduksi barang pakai seperti baju, undangan, emblem, badge, plang nama dan masih banyak lagi. Intinya adalah berkaitan dengan menduplikasi gambar. Pada saat kuliah, penulis berhadapan dengan seni grafis dalam konteks seni murni yang mana seni grafis tersebut digunakan sebagai media berekspresi. 
Setelah mengalami kedua hal ini dan mengetahui kaidah/esensi dari seni grafis kemudian muncul dalam pikiran penulis terhadap hal-hal yang mengandung kaidah seni grafis tersebut tetapi tidak termasuk ke dalam seni grafis terapan maupun murni. Kaidah-kaidah seni grafis adalah :

1. Proses mencetak

Kaidah ini merupakan hal yang paling esensial dalam seni grafis. Seperti yang dikatakan Maryanto dalam seminar Pekan Seni Grafis Yogyakarta bahwa fitrah dari seni grafis adalah menciptakan sebuah jejak pada media cetakan yang dapat direproduksi sesuka hati ${ }^{1}$.

2. Matriks

Berasal dari Bahasa Latin "Mater" yang berarti ibu. Matriks adalah permukaan tempat seniman menciptakan gambar sebelum dicetak; misalnya, woodblock, linoleum, plat logam, batu litograf, atau layar mesh. ${ }^{2}$

3. Edisi

Edisi merupakan kaidah yang tercipta karena fungsi pertama seni grafis yang digunakan untuk memperbanyak gambar. Ketika seni grafis masih digunakan sebagai alat memproduksi gambar. Edisi merupakan salah satu ciri khas seni grafis yang kuat dimana meskipun ada 100 edisi dari sebuah karya, semua edisi tersebut masih dikatakan sebagai karya orisinil bukan tiruan, imitasi ataupun copy-an. Dalam kaidah ini terdapat salah satu sifat dari seni grafis yang repetitif.

4. Dua dimensi

Kaidah ini adalah yang membatasi/memisahkan antara seni grafis dengan seni patung. Dimana di dalam seni patung ada juga teknik mencetak. Hanya saja dalam seni patung hasil

\footnotetext{
${ }^{1}$ Maryanto, Printmaking dan Seni Kontemporer, Seminar Pekan Seni Grafis Yogyakarta, 2017, p.3

${ }^{2} \mathrm{http} / / /$ www.ifpda.org/glossary_term/3314 diakses 24 Oktober 2018 pukul 08.50 WIB
}

\section{UPT Perpustakaan ISI Yogyakarta}


cetakan tersebut bersifat 3 dimensi sedangkan seni grafis bersifat 2 dimensi terlepas dari media cetaknya.

Melalui pemikiran di atas, penulis juga menjumpai kaidah-kaidah seni grafis di atas pada kehidupan sehari-hari. Kaidah yang ditemui penulis salah satunya adalah proses mencetak yang terdapat pada jejak. Meskipun jejak yang mengandung kaidah seni grafis tidak bisa serta merta disebut sebagai seni grafis. Karena tidak semua jejak terdapat proses mencetak dan seni grafis telah mempunyai konvensi yang telah disetujui.

Di samping itu, penulis mendalami lagi tentang kata jejak tersebut. Dalam Kamus Besar Bahasa Indonesia, jejak merupakan bekas yang menunjukkan adanya perbuatan dan sebagainya yang telah dilakukan ${ }^{3}$. Melalui pengertian ini dapat diidentifikasi bahwa jejak tercipta dari sebuah aktifitas. Karena aktifias tersebut menyebabkan jejak, maka sebuah jejak dapat mengungkapkan sesuatu terkait sebuah aktifitas. Selain itu, dari sebuah aktifitas dapat ditimbulkan jejak yang tidak kasat mata. Jejak tersebut adalah yang berada dalam pikiran manusia yaitu pengalaman. Pengalaman- pengalaman tersebut ada yang hanya berlalu dan ada pula yang membekas. Salah satu faktor yang membuat pengalaman menjadi dapat dikarenakan aktifitas yang menjadi sumber pengalaman tersebut dilakukan secara berulang-ulang. Dengan berulang-ulang tersebut lamakelamaan mengendaplah pengalaman tersebut sehingga membekas. Aktifitas yang dilakukan secara berulang-ulang tersebut disebut dengan rutinitas. Dalam rutinitas, karena terjadi pengulangan-pengulangan yang sama, penulis juga melihat hal tersebut seperti saat mencetak edisi dari seni grafis yang bersifat repetitif. Meskipun diulang ulang, setiap rutinitas merupakan aktifitas yang otentik.

Pengalaman yang tercamkan tadi berisi tentang emosi, ilmu, ekspresi, memori dan lain sebagainya yang tercamkan dalam pikiran manusia. Jadi, segala sesuatu yang dilakukan manusia pada dasarnya

\footnotetext{
${ }^{3}$ Hasan Alwi (ed.), Kamus Besar Bahasa Indonesia, (Jakarta : Pusat Bahasa Departemen Pendidikan Indonesia, Balai Pustaka, 2005), p.573
} 
berdasar pada pengalaman semasa hidupnya. Mulai dari bangun tidur sampai tertidur kembali manusia melakukannya berdasar pengalaman.

Hal-hal yang terkait dengan seni grafis pada kehidupan penulis lah yang melatarbelakangi penulis dalam membuat karya. Sampai saat ini kedua hal tersebut adalah rutinitas sehari-hari dan jejak yang sudah dijelaskan sedikit di atas. Selain terkait dengan esensi seni grafis, rutinitas sehari-hari dan jejak juga merupakan hal yang saling berhubungan satu dengan yang lain. Rutinitas dapat menimbulkan sebuah jejak dan jejak dapat digunakan untuk mengungkapkan sebuah rutinitas yang mengakibatkannya.

\section{B. Rumusan Penciptaan}

Berdasarkan latar belakang di atas, maka masalah pokok yang dapat dirumuskan untuk penciptaan ini selanjutnya adalah :

1. Citra repetisi seperti apakah di balik karya-karya seni grafis?

2. Representasi pengalaman pribadi apa saja yang mendasari karya?

3. Bagaimana memvisualisasikan gagasan ke dalam karya seni menggunakan teknik seni grafis?

4. Medium-medium apa saja yang digunakan?

\section{Tujuan}

1. Menjelaskan citra-citra repetisi di balik karya seni grafis.

2. Mendeskripsikan representasi pengalaman pribadi melalui seni grafis.

3. Memvisualisasikan gagasan citra repetisi dalam seni grafis

4. Mengeksplorasi medium dalam seni grafis.

\section{Manfaat}

1. Mengaktualisasi diri dalam memaknai hidup melalui karya seni.

2. Memantik para mahasiswa seni grafis supaya lebih maksimal dalam mengeksplorasi seni grafis baik dari segi wacana maupun teknik.

3. Memberi tambahan pengetahuan bahwa seni grafis merupakan salah satu cabang seni yang sebenarnya dekat dengan masyarakat. 


\section{E. Makna Judul}

Penulis memberi judul "CITRA REPETISI DALAM SENI GRAFIS" Untuk medeskripsikan praktik penciptaan yang dilaksanakan dalam karya tugas akhir ini. Untuk membatasi pengertian makna kata yang digunakan dalam judul penulisan tugas akhir ini, maka dapat dijabarkan pengertian khusus dari kumpulan kata yang digunakan dalam judul penulisan tugas akhir ini, yakni :

Citra $\quad:$ Kesan batin/ mental atau bayangan visual yang ditimbulkan oleh objek/ figure dalam karya seni rupa. ${ }^{4}$

Repetisi : Pengulangan bentuk-bentuk, teknik atau objek dalam karya seni. ${ }^{5}$

Seni Grafis : Dalam pengertian umum, istilah seni grafis meliputi semua bidang seni visual yang dilakukan pada suatu permukaan dua dimensional sebagaimana lukisan, drawing atau fotografi, lebih khusus lagi pengertian istilah adalah sinonim dari printmaking (seni mencetak). dalam penerapannya seni grafis meliputi semua karya seni dengan gambaran orisinil apapun atau desain yang dibuat oleh seniman untuk direproduksi dengan berbagai proses cetak. ${ }^{6}$

Berdasarkan uraian di atas, maka yang dimaksud dengan judul penciptaan "Citra Repetisi dalam Seni Grafis" yaitu penulis ingin mengungkapkan kesan-kesan yang ditimbulkan oleh pengulanganpengulangan yang terdapat dalam kehidupan sehari-hari melalui karya seni grafis.

\footnotetext{
${ }^{4}$ Mikke Susanto, Diksi Rupa : Kumpulan Istilah dan Gerakan Seni Rupa, (Yogyakarta : DictiArt Lab, 2011) p.82

${ }^{5}$ Ibid p.332

${ }^{6}$ M. Dwi Marianto, Seni Cetak Cukil Kayu, (Yogyakarta : Kanisius, 1985) p. 15
}

\section{UPT Perpustakaan ISI Yogyakarta}

